\title{
On the Development of Business English Majors in Colleges and Universities Promoting Regional Development under National Standard
}

\author{
Xie Xiuzhen \\ Foreign Languages \\ Guangzhou College of Technology and Business School \\ Guangzhou 510800; \\ xiexiuzhen1018@163.com
}

\author{
Gao Fengjiang \\ Foreign Languages \\ Guangzhou College of Technology and Business School \\ Guangzhou 510800;
}

\author{
Huang Hongwu \\ Department of Economics \\ Guang Dong Peizheng College \\ Guangzhou 510800
}

\begin{abstract}
Under the background of the "Belt and Road" initiative and the implementation of innovation and entrepreneurship education, education diversity emerges in domestic colleges and universities. However, the construction of disciplines is the core of the development of higher education. This paper took the national quality standard of business English professionals, combined the insights of scholars on the interpretation of the various elements of the national standard, proposed that the business English major should achieve rapid development under the guidance of the spirit of the new national standard. According to the theory of ecology and resource allocation, it is necessary to explore a new way to promote the regional development through the service of discipline and specialty construction, and to form the unique characteristics and development path of Business English majors in each university.
\end{abstract}

Keywords - national standards of business English; Business English major; regional development; ecological theory; resource integration

\section{INTRODUCTION}

China's higher education has been widely popularized, and the gross enrollment rate of higher education has reached $42.7 \%$. It strives towards the internationally recognized popularization standard of higher education. In accordance with the national higher education talent training goal, in 2015, the Ministry of Education formulated the National Standards of Teaching Quality for Undergraduate English Majors (hereinafter referred to as the National Standards) which standardizes and clarifies the international, composite and applied talents training of the business English, and meets the needs of China's economic opening up. According to the Outline of the National Medium- and Long-term education Programme for Education Reform and Development (2010-

This paper is one of the periodic achievements of important projects of Guangdong Province Foreign language Studies in philosophy and Social Sciences "A study on the speculative ability training of Foreign language majors under the guidance of National Standards". (PROJECT NO.GD16WXZ20)
2020), China is implementing the "Belt and Road" macrostrategy, the economy is in key period of rapid development, and industrial upgrading and transformation. China replaced Japan as the world's second largest economy in 2010. And the development of foreign trade is rapid. The trade volume between China and the world has increased nearly 20 times in the past 20 years [1]. The high-speed economic growth requires more high-quality talents.

There are 1,145 undergraduate colleges and universities in the country, of which 994 have set English majors. However, it is an indisputable fact that undergraduate English majors face enormous employment challenges [2]. Due to the lack of "hierarchic optimization" and "individual features", the quality of undergraduate English majors tends to decline [3]. The specifications of Business English talents trained in many universities are not fully in line with the requirements of enterprises (MyCOS Institute 2013). The Business English majors in colleges and universities have a strong homogenization tendency, lack of characteristics, and are out of touch with regional social development while neglecting the cooperation with regional development. These are also the inevitable shortcomings in the development of business English. It is undeniable that specialty building is more and more closely related to social development and regional development. Education is no longer a ivory tower.

\section{ACADEMIC IDEAS AND REFLECTIONS ON THE} CONSTRUCTION OF BUSINESS ENGLISH MAJORS

The Business English undergraduate aims to cultivate talents that are based on foreign language and literature, applied economics, business administration, law (international business law), etc., it emphasizes the use of business language, business knowledge learning and practice, and cross-cultural business communication skills. [4] In order to solve the above dilemma of Business English majors, Zhong Weihe [5] pointed out that diversity, flexibility and autonomy are the 
development goals of English majors in the future. All universities should explore a diverse talent development program by taking into consideration the national and regional economic and social development requirements for talents and the school's ability of running a school. After the formulation of the "national standards of business English", some scholars conceive, interpret and explore the connotation and key points of the national standard over how to build a good business English major.

\section{A. The combination of national standard and school standard}

In Sun Yi's 'Local Interpretation of National Standards for Undergraduate Teaching Quality of Business English Majors in Colleges and Universities: Comparison of National Standards and School Standards", a horizontal comparison of professional orientation was conducted on the business English major of Xi'an International Studies University. It proposed that universities should take the road with connotative and sustainable development from the practical standpoint. The national standard provides only a standard model, and local colleges and universities need to combine the local ecological environment to carry out various professional construction works [6].

\section{B. Professional course module}

As the professional curriculum system directly affects the teaching effect, the Business English professional curriculum system must be developed based on the school condition, teacher status, hardware and software conditions, academic situation, teaching resources and so on. The differentiated curriculum system can also achieve common training objectives. Zhang Wenzhong and other scholars proposed innovative ability training curriculum modules in the English majors training curriculum. The modules are classified into "personalized learning and discussion", "initial research methods", "English professional project study" and "project writing" [7], to train students' deep learning, critical thinking skills, innovative problem solving ability. Business communication is the core content of Business English major. Both the curriculum system and professional curriculum teaching cannot be separated from the requirements of actual business world. How to narrow the gap between classroom and social practice is an urgent problem we should solve in the curriculum system construction.

\section{Quality level of talent training}

Zhang Delu explored the multi-functional structure of undergraduates major in foreign language. Under the ever changing external environment, he determined the multidisciplinary abilities of undergraduates major in foreign languages, that is, high-level abilities and middle-level abilities The former one includes foreign language communication ability, professional comprehensive ability, interdisciplinary ability, knowledge processing ability, cultural comprehensive ability, media modal operation ability, critical reflection ability, and social interaction ability [8]. In order to meet the national, social and student needs, Zhang Wenzhong and other experts, take the school resources and regional characteristics into account, have envisaged the ability tree for the quality of "school standards" for English professionals talents, and constructed a "school standards" capability map - including "roots” (basic capabilities), "trunks" (language application and innovation), the "main branch" (from simple cognition to complex cognitive tasks) and the "canopy" (professional to high-level comprehensive literacy). The ability tree emphasizes the of "roots" and "trunks" and highlights the cultivation of the two main characteristics of the "main branch" and the "canopy".[9]. Yuan Xin and others scholars analyzed the application-oriented Business English talents training specifications based on the corporate recruitment advertisements, and they found that enterprises focus on whether the candidates have the comprehensive quality of completing the job. They put forward higher requirements of "professional quality" in the talents' specification. Employees should work actively, they must be able to work under pressure, coordinate with others, and even have a high sense of identity about work. [10]

\section{Professional teachers' development}

Scholars have discussed the construction of business English majors from various levels according to the spirit of the national standard, but they did not cover how to serve the characteristics of regional economy under the background of "Belt and Road" and "entrepreneurship and innovation" strategy when universities and colleges construct the Business English major.The talents service is a strong driving force for regional economic growth. To build a linguistic discipline system with Chinese characteristics, we must take a distinct path.

\section{THE THEORETICAL BASIS FOR BUSINESS ENGLISH MAJORS CONSTRUCTION SERVEING THE REGIONS}

There are three basic links in resource integration, namely, identifying resources, attracting resources, and transforming individual resources into organizational resources, which transform internal and external resources into sustainable competitive advantages of enterprises (Brush, 2001). Similarly, to obtain a sound and sustainable development, universities should integrate resources. Mascitelli believes that resource integration is "improvisation", and it is necessary to fully exploit the "invisible assets". For universities, in addition to their own resources, regional resources, including government, enterprises, and industries associations, industrial advantages, geographical features and other resources must be taken into account. In order to enhance the awareness of talent serving regional development, major construction should follows the regional demand, to create its own distinctive and competitive specialty [11]. In addition, to serve the regional development, we must think in a grand view. The "ecological theory" provides a strong theoretical support for the sound development of colleges and universities. The university is an important base for the construction of ecological civilization. The construction of business English major should be combined with the ecological concept. "Ecological" emphasizes the interconnection, interaction and functional unity of the various factors in the system [12]. The construction of Business English major is a dynamic process, which needs to be related to the surrounding environment. The "small" 
system inside the university and the "big" ecosystem of the external society continuously exchange energy and information to create a harmonious ecological civilization.

\section{MEASURES TO ACHIEVE SERVICE REgIONALIZATION OF BUSINESS ENGLISH}

The Business English major should truly establish a mutually beneficial and win-win cooperation model with local governments and enterprises. A consensus must be reached at the macro and micro levels.

\section{A. Actively participate in the "Belt and Road" initiative and Innovation and Entrepreneurship education, do a good job in professional construction}

"The Belt and Road" involves Japan, South Korea, Central and Western Asia, Southeast Asia, Eastern and Western Europe, Africa and other countries. China and some of them have established China-Australia Free Trade Zone, China-New Zealand Free Trade Zone, China-Japan-Korea Free Trade Zone, and China-ASEAN Free Trade Area. Today, when English is regarded as a global language, the "Belt and Road" initiative undoubtedly provides unprecedented opportunities as well as challenges for the development and employment of business English professionals. The higher the level of work, the more comprehensive ability of job seekers (language skills, crosscultural Knowledge, business skills, professional practice, etc.) is required, and therefore, the weaker the substitutability of talent. From 2015, for example, the Foreign Languages Department of Guangzhou College of Technology and Business has organized students in Business English to go to Malaysia's top 500 Scicom (MSC) Berhad and other wellknown enterprises to participate in overseas internships and open up students' horizons. Since 2011, they have organized classes to participate in the practical activities in Canton Fair and signed cooperation agreements with Guangzhou enterprises. This kind of school-enterprise cooperation not only promotes the enthusiasm of students, but also gives teachers the practical opportunity of doing post work in the winter and summer vacations. Guangzhou College of Technology and Business advocates dual-teachers, that is, Business English professional teachers take advantage of the job opportunities to serve translation companies, exhibition companies, foreign trade companies, catering management companies, hotels, travel companies, Huadu Shiling luggage companies in Guangzhou, other small and medium-sized companies, which have achieved good social benefits and enhanced the practical Business English skills of the teachers and understanding of social talent needs. Moreover, it helps to have a more intuitive understanding of business operating environment, culture, management, marketing, international trade and other work, which is closer to the enterprise, improves the teaching effect of teachers. Through the practical activities of teachers and students, the bond of exchanges and cooperation between businesses and other regions has been established, so as to promote the healthy development and the establishment of a professional foundation, thereby leading schools, businesses, students and teachers to get a win-win situation.

Innovation and entrepreneurship education is the characteristic of higher education and an important development. As Etzkowitz said, the innovation economy plays a key role in China's growth. There are various participants in the national innovation system, such as universities, industries and government agencies [13]. They provide opportunities for communication, creation and dissemination of knowledge across levels (ie countries, regions and sectors) for technological development. Karlsson recommends that SME researchers form a close teamwork relationship internally and establish a close external localization relationship with universities and research institutions [14]. Therefore, corporate development is inseparable from professionals. The development of the macro-level national policy education is an important factor that cannot be ignored in the construction of business English major.

\section{B. Based on the characteristics of regional differences, identify the "origin of force "of innovation}

According to the characteristics of regional economic development, the key to finding the talents market is to understand the comprehensive development of the region and the needs of enterprises. Just as the universities in Guangdong, they focus on the characteristics of Guangdong Province to produce talents to serve the province, with "regional" and "high level" as the core of high-level university construction. [15] Business English majors in colleges and universities actively cooperate with enterprises in the region through industry-university-research methods, combining advanced concepts and technologies with practical applications, upgrading local industrial structures, attracting investment services and stimulating the economic growth.

\section{Explore the connotation of Business English major construction, and strengthen the linkage development of colleges and social ecosystems}

Under the innovation and entrepreneurship education, strengthen the optimization of the talent training system, build a multi-level innovation and entrepreneurship talent training practice system with the curriculum practice inside and outside the school, internship training, and project platform. Optimize the professional curriculum system. On the basis of the characteristics of the school, we establish innovation and entrepreneurship basic curriculum and practical curriculum for the regional economic development. We will enhance students' knowledge and experience through the extended second classroom, learn from experienced experts in regional enterprises and companies, and work with teachers in the school to create an innovation and entrepreneurship teaching team by apprenticeship education, set up entrepreneurship and innovation personnel training practice system with regional enterprises and institutions

Universities and colleges within regions should enhance interaction, resource sharing, and harmonious development, break the institutional barriers between universities and disciplines and internal mechanisms, promote linkage development between universities, and achieve win-win cooperation, and jointly build excellent Business English majors. 


\section{CONCLUSION}

At present, China's "Double First-Rate" construction of universities and disciplines has been implemented. To build the characteristics of Business English majors, it's our goal to enhance core competitiveness, and utilize internal and external resources with the guidance of the national standard under the development of the new situation; we should focus on and serve regional development.

\section{REFERENCES}

[1] Su Yi. Chinese Culture "Going Out” Strategy under National Cultural Security Strategy[J]. Jinan Journal, 2010,2015:5

[2] Zhong Meisun. Implementing National Standards for Undergraduate Teaching Quality and Promoting Teaching Reform and Development of Foreign Language Majors[J]. Foreign Language World, 2015, (2): 2-6.

[3] Zhong Weihe, Pan Mingwei.On the Formulation of National Standards for Undergraduate Teaching Quality in English Majors: Innovation and Reflection[J]. Modern Foreign Languages, 2015 (1) 112-120

[4] Wang Lifei, Gehailing..The Quality, Knowledge and Ability of Chinese English Majors and Their Differences: Interpretation of National Standards[J]. Foreign Language World, 2015(5): 4.

[5] Zhong Weihe.The Innovation and Development of English Majors under the Guidance of the National Standards for Undergraduate Teaching Quality of English Majors[J]. Foreign Language World, 2015(3):2-8.

[6] Sun Yi. Local Interpretation of National Standards for Undergraduate Teaching Quality of Business English Majors in Colleges and
Universities: Comparison of National Standards and School Standards[J] Foreign Language World, 2016,(2) 46-57

[7] Zhang Wenzhong, Feng Guangwu. Thoughts on the Innovative Ability Train ing Courses for English Majors[J]. Foreign Languages and Their Teaching, 2015(3): 29.

[8] Zhang Delu, Chen Yixi. On the Structure of Multiple Ability of Undergraduates in Foreign Languages in China[J]. Foreign Language World, 2015 (6): 2-10.

[9] Yuan Xiang et al. On the Training Specifications of Applied Business English Talents Based on the Analysis of Enterprise Recruitment Advertising Demand. Foreign Language and Translation 2017, Iss 2, 93 (82-88)

[10] [Brush C, Greene P, Hart MM..From initial idea to unique advantage:The entrepreneurial challenge of constructing resource base. [J].Academy of Management,2001,15.

[11] Mascitelli R. 2000, From experience: harnessing tacit knowledge to achieve breakthrough innovation ,Journal of Product Innovation Management,17(3):179-193

[12] Liang Jianhui.Ecological Thin king on the Moral Education Concept and Behavior Realization in Modern Colleges and Universities[J]. Modern Education Science, 2016,(6):74-77

[13] Etzkowitz, H., and Leydesdorff, L .,2000. The Dynamic of Innovation:From National Systems and "Model 2"to a Triple Helix of University-industry-government Relations: Research Policy, 29:109-123.

[14] Karlsson Charlie,Borge Johanson, Kiyoshi Kobayashi and Roger R. Stough (eds.),2014.Knowledge, Innovation and Space. Cheltenham:Elgar.

[15] Liu Hui, Li Jing. Provincial High-level University Construction Policy: Historical Evolution and Value Selection. 2017, March, Iss 3, Vol 38, pp $31-36$ 